\title{
Speleomorphology of M3-R2 - The highest cave in the SE Carpathians
}

\author{
Laura TÎRLĂ ${ }^{1 *}$, Virgil DRĂGUȘIN ${ }^{2}$, Ionuț MIREA ${ }^{2,3}$, Teodor COJOCARU1 \\ ${ }^{1}$ Faculty of Geography, University of Bucharest, Bucharest, Romania \\ ${ }^{2}$ Emil Racoviță Institute of Speleology, Romanian Academy, Bucharest, Romania \\ ${ }^{3}$ Faculty of Biology and Geology, Babeș-Bolyai University, Cluj-Napoca, Romania \\ Received 12 October 2016; Revised 20 October 2016; Accepted 22 October 2016 \\ *Correspondence to: Laura TîRLĂ, e-mail: tirla@geo.unibuc.ro
}

\section{ABSTRACT}

High-alpine caves are currently in the spotlight of research as they are host to speleothems, key recorders of Quaternary environmental change. Based on modern survey and analytical techniques, we investigated the karst morphology of M3-R2 Cave, the highest alpine cave in the Romanian Carpathians. Spatial modeling in Compass has shown survey details and cave morphology. We recalculated the main cave parameters (development/extension/depth), obtaining $47 \mathrm{~m} / 21 \mathrm{~m} /-18.15 \mathrm{~m}$, respectively. Slope ranges between $25^{\circ}$ and $45^{\circ}$, with short passage segments of $5^{\circ}$ to $10^{\circ}$. The cave developed at the intersection of a SW-dipping schistosity plan with two fracture sets, occurred under compression conditions. It is a remnant of a once longer cave system, which was progressively eroded under glacial conditions. Speleothem diversity is uncommonly rich for a marble cave, with dominant moonmilk formations, stalagmites and draperies. Due to its location/elevation, evolution and speleothems, this cave has a great potential in providing important paleoclimatic information compared to other karst landforms in South Carpathians.

\section{KEYWORDS}

karst, cave survey, geomorphological mapping, Făgăraș Mountains, South Carpathians

\section{Introduction}

According to Bögli's simple and concise definition, 'speleomorphology is cave-oriented geomorphology, the description and interpretation of the forms in the underground which are due to corrosion, erosion, and breakdown', excluding the forms which are the result of sedimentation (Bögli, 1980). Analysis of cave morphology - the size, shape, mineral deposits, and patterns - provides abundant information on the present or past behavior of the groundwater flow system (White \& Culver, 2012). High-alpine karst is of particular importance as it develops under certain climate conditions in a cold 
environment and is able to better record the changes typical to climate islands (Hedberg, 1964).

In this study we conducted a preliminary work on the morphology of M3-R2, a high-alpine cave developed in the metacarbonate stripes which occur in Făgăraș Mountains, South Carpathians. This cave is located at the highest elevation in Romania (2430 $\mathrm{m}$ a.s.l.). It was discovered and preliminarily surveyed in 1989 by a team of speleologists from the 'Emil Racoviță' Speleological Club (CSER) in Bucharest (Giurgiu, 2006). Ancient speleothems of M3-R2 were subject to paleoclimatic investigations and found extremely interesting as recorders of past interglacials (Drăgușin, 2013). We performed a complete survey, cave mapping and preliminary geomorphological analysis with modern cave survey instruments and methods. This study is part of a multidisciplinary research project that our team is currently carrying out in the alpine Mușeteica area in Făgăraș Mountains. Extended research on the entire karst system will result in a proper interpretation of underground morphology and speleogenesis of M3-R2 and the other caves from this area.

\section{Geographic and geological setting}

The M3-R2 cave (cadastral number 2015/19) is located at $2430 \mathrm{~m}$ a.s.l. in the central ridge-crest area of Făgăraș Mountains, 12 meters below Peak Mușeteica (2442 m a.s.l.) - Fig. 1 and Fig. 2. Karst features are developed in the metacarbonate rocks or marbles in the amphibolites facies, retromorphosed to greenschist facies (Giușcă et al., 1977). Metacarbonates are hosted by medium-grade amphibolites facies in the Moldoveanu Nappe (Balintoni, 1986), the uppermost Supragetic Unit in Făgăraș Mts.

Reported radiometric ages of its thrust plane were 114-102 Ma (Lemne et al., 1983), indicating that the nappe was emplaced during the Middle Cretaceous Austrian tectogenesis.

Six caves were discovered and surveyed in the Buda-Museteica marble enclave at the end of the '80s: M1, M2, M3-R2, R1, M4 and M5 (Giurgiu, 1990,
2006). All these caves are presently located at elevations between $2090 \mathrm{~m}$ and $2430 \mathrm{~m}$ a.s.l. Only some small caves formed by distension in schists in the nearby Lespezi Mt exceed these elevations (2493-2512 m). The role of marble stripes in shaping the geomorphological diversity of alpine landscape in Făgăraș Mountains was outlined by Nedelea (2006a, 2006b). Karren, sinkholes, caves and potholes resemble the alpine karst morphology.

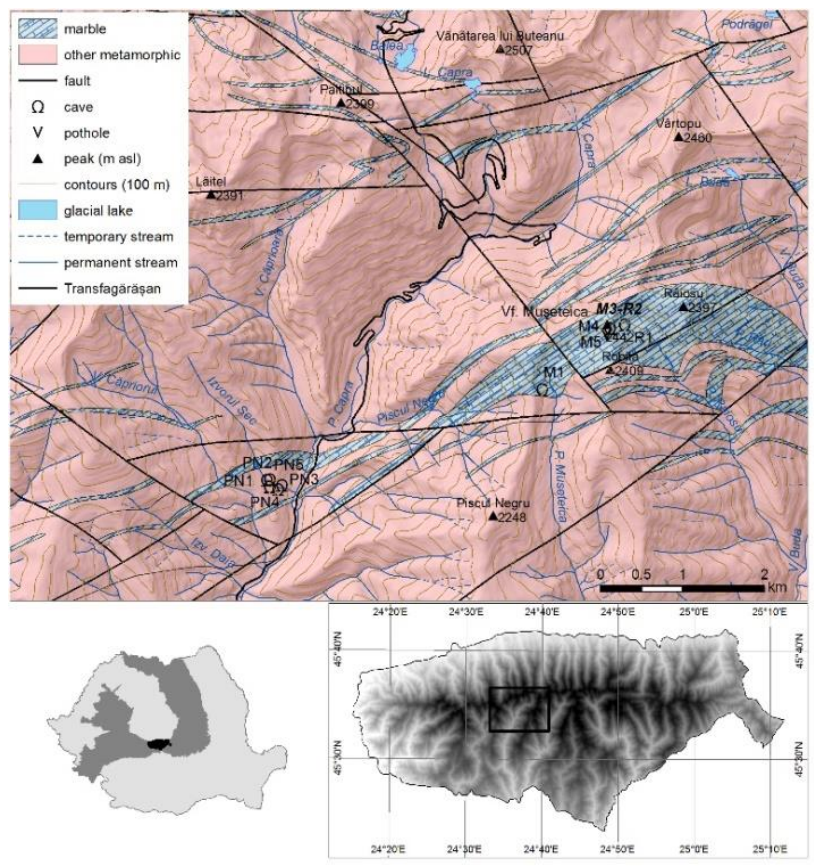

Figure 1 Geographic and geological setting of the caves in the upper valley of Argeș river, with M3-R2 outlined

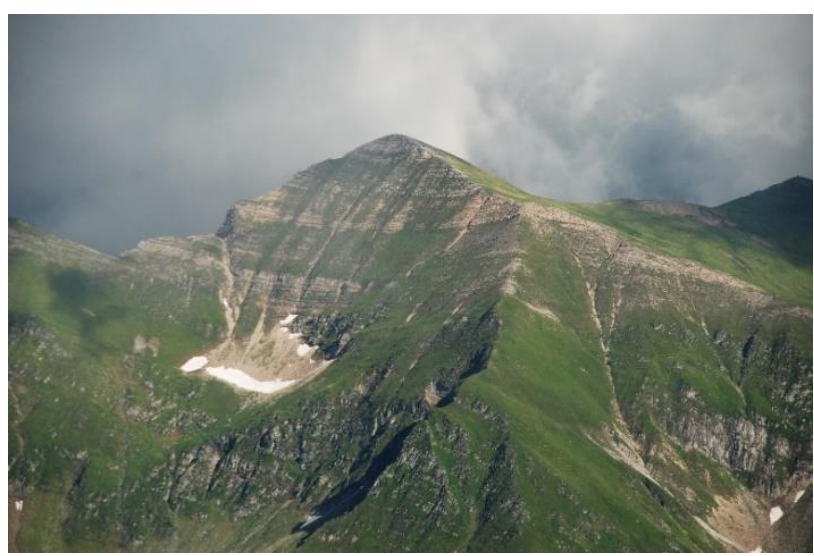

Figure 2 Mount Mușeteica (2442 m a.s.I.) displaying schistose metacarbonates 
Results from continuous monitoring of microclimatic parameters in M3-R2 cave from April to October 2012 have shown that the air temperature is about $2-2.5^{\circ} \mathrm{C}$ during winter and variable after snow melting (up to $4.5^{\circ} \mathrm{C}$ ), probably due to ventilation (Drăgușin, 2013). The shallow depth $(10-15 \mathrm{~m})$ and passage shortness makes it vulnerable to outer climatic changes.

\section{Methodology}

During field work we used a topographic map 1:25,000 (DTM, 1980) and the geological map 1: 50,000 (Schuster, 1977). Structural measurements on joints, foliation planes and faults were performed using a Freiberger geological compass. Cave survey was carried out using a Disto $^{\mathrm{TM}}$ X310 device from Leica Geosystems ${ }^{\circledR}$, and professional speleological equipment. GPS measurements taken with a Garmin eTrex Vista ${ }^{\circledR} H C x$ were useful for the reassessment of cave elevation.

Cave survey data processing was performed using the open source Compass application. The resulted main survey lines, stations and depths served to further mapping (Fig. 3). We measured orientations of linear tectonic features in $\operatorname{ArcMap}^{\mathrm{TM}}$ using the ArcGIS 10 EasyCalculate 10 Add-Inn (Tchoukanski, 2010). The final map and profile were designed in Corel DRAW ${ }^{\mathrm{TM}}$.

Geomorphological mapping of subsurface karst features was made according to UIS symbology (Häuselmann, 2008), with details adapted from (Sencu, 1973). We created a detailed color map of M3-R2, given its modest size and morphological variety. Slightly different colors were used to emphasize the two main morphological components, speleothems and breakdown: white for calcite precipitation forms, and light grey (RGB code $245,245,245)$ for breakdown. Clayey sediment was emphasized by a light brownish color $(217,195$, 139), and depth contours with annotations by a reddish-brown color $(153,102,51)$. Passage walls and shafts were drawn using 0.5 -width lines, $1^{\text {st }}$ order morphology (e.g. steps) with 0.3-width lines, and $2^{\text {nd }}$ order morphology (e.g. breakdown, contours) with 0.25 -width lines.
Cave morphometry was calculated using the analytical techniques recommended by Povară et al. (1990). The module-based cumulative length was used to calculate cave development, the other parameters resulting directly from cave survey data. The map text box contains the projected distances representing cave development and extension. Orientation data were given in relation to magnetic north $\left(\mathrm{N}_{\mathrm{m}}\right)$. Knowing that the magnetic declination of the cave location is $+5.39^{\circ}$ (positive), the geographic north should be considered in this sense.

\section{Results and discussion}

\subsection{Cave morphology}

The cave entrance has a NNE-SSW orientation $\left(9.7^{\circ}\right)$. In its immediate vicinity another two passage entrances can be explored, which obviously were part of the cave system in the past. Dissolution and gravitational processes have caused the formation of a collapse sinkhole at the intersection of the two remnant passages, which cannot be considered as being part of the cave at present. The collapse sinkhole has an ellipsoid shape $(6.1 \mathrm{~m}$ in length, 3.2 $\mathrm{m}$ in width, and $0.5 \mathrm{~m}$ in depth) and its bottom is filled with rock fragments and clayey sediment. It is the highest-elevated sinkhole reported in the Romanian Carpathians. When it was surveyed for the first time, the ' \pm 0 ' level was taken at the B-lettered entrance, which makes logic if the cave passage was accessible through this passage. But this passage remnant is completely isolated from the cave by breakdown, so we reconsidered the setting of ' \pm 0 ' level.

This resulted in a different depth of M3-R2 cave, $-18.15 \mathrm{~m}$ compared to previously reported depth of -20 m (Giurgiu, 2006). The cave is generally small, consisting in two main chambers separated by a $0.5 \mathrm{~m}$-thick wall of rugged boulders cemented with calcite (Fig. 4). The cave entrance is very small $(0.6 \times$ $0.8 \mathrm{~m})$, followed by a narrow, steep passage, which responds to the small chamber. A 1.3-meter double shaft connects it to the large chamber, which ends with an impenetrable ceiling-floor junction filled with sediment and breakdown up to $1.3 \mathrm{~m}$ in diameter. 

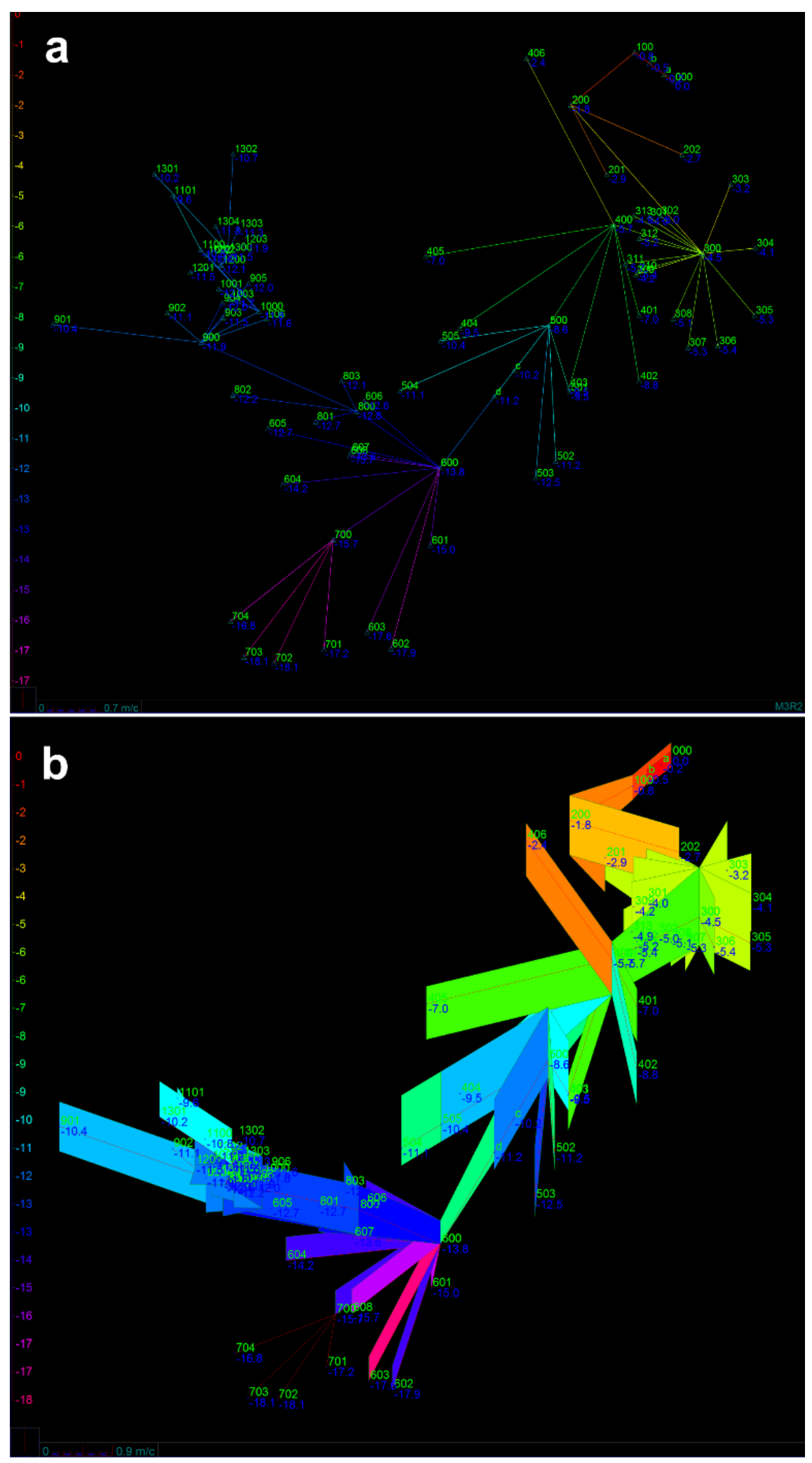

Figure 3 Modeling cave morphology in Compass

(color-by-depth mode): a. Cave plan; b. Projected longitudinal profile 


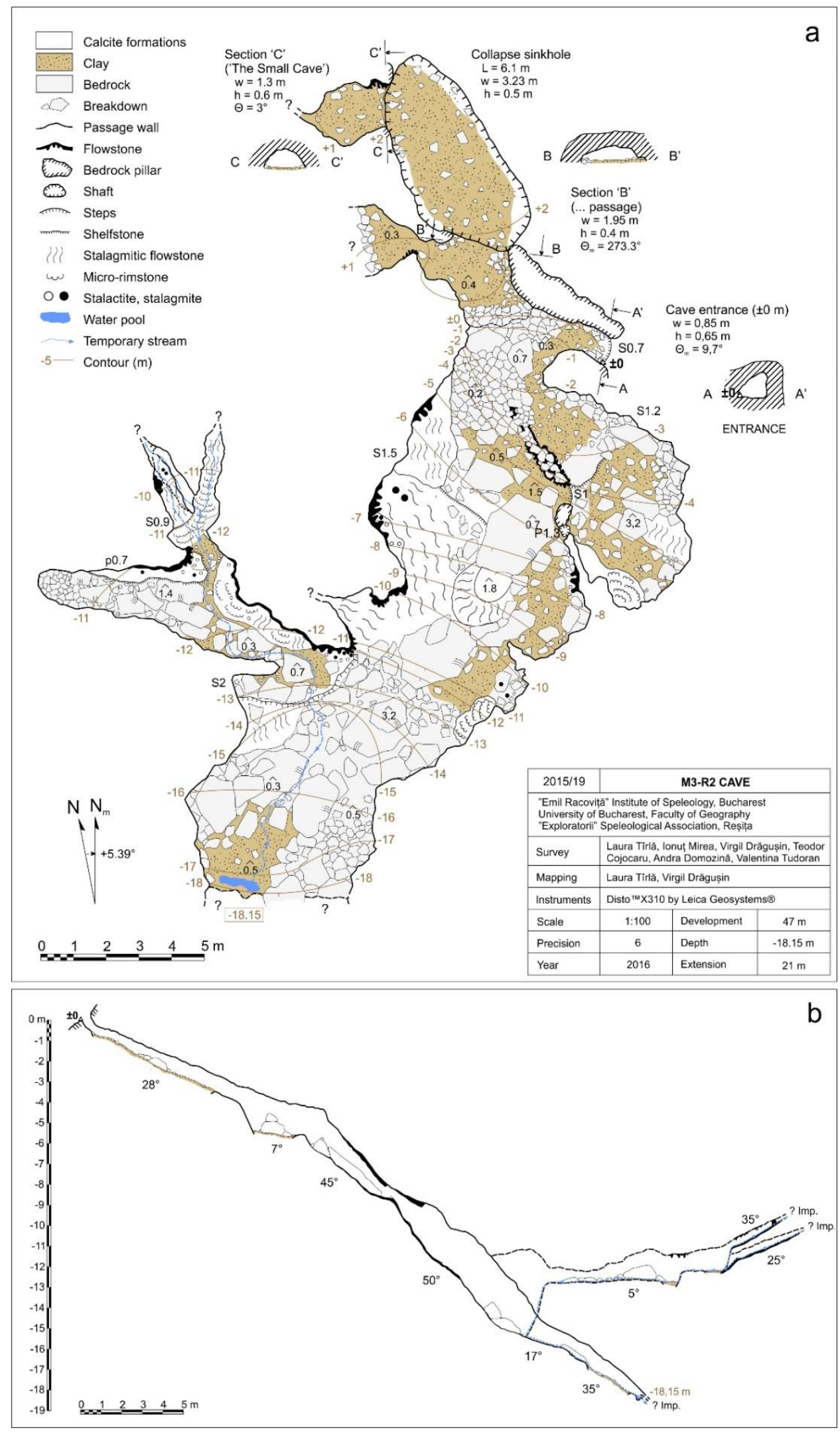

Figure 4 Cave map: a. Plan; b. Unfolded longitudinal profile 

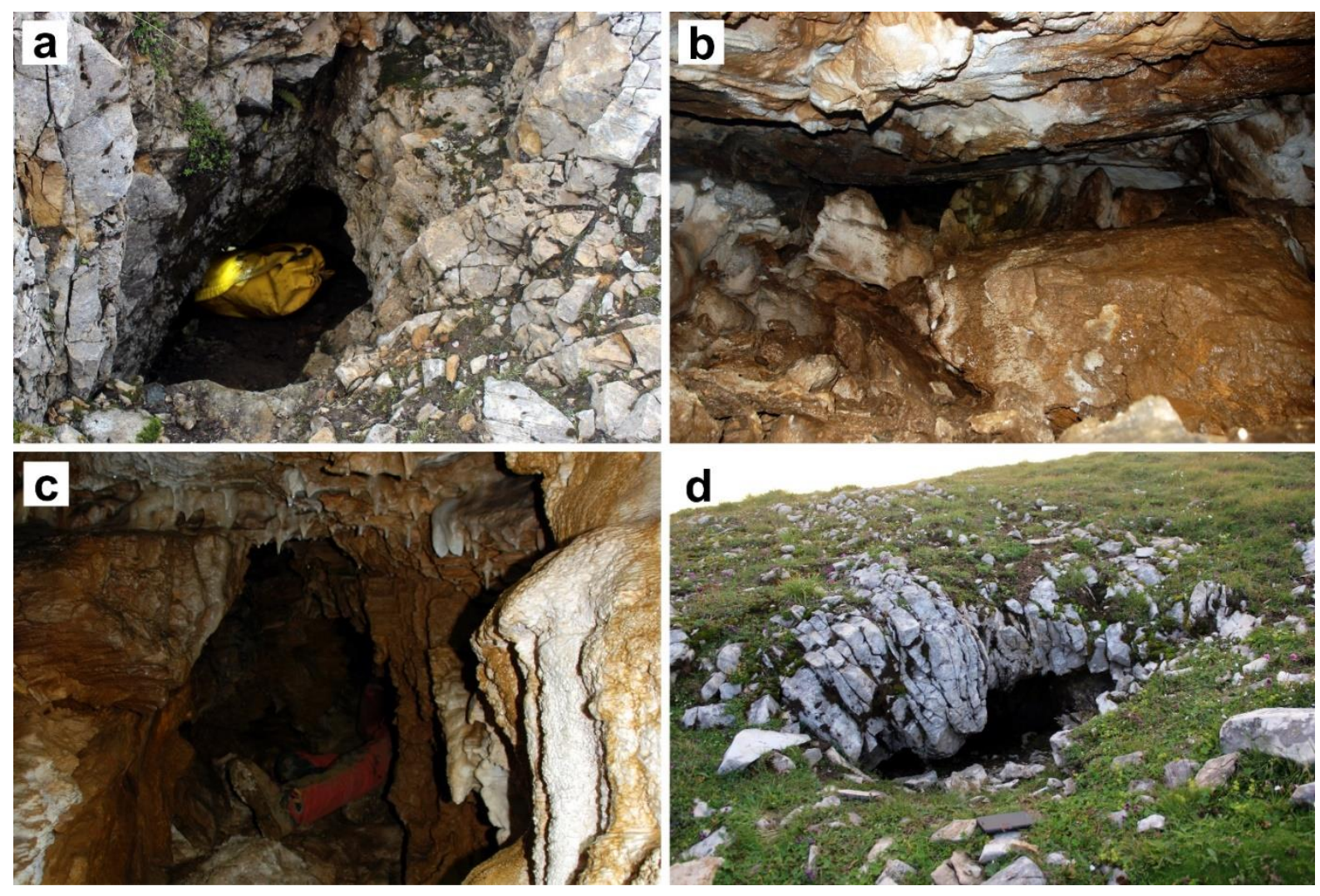

Figure 5 Cave morphology: a. Cave entrance (caving bag for size); b. The main chamber; c. 'The Pocket'; $d$. Entrance in a remnant cave passage ('The Small Cave'). Author credentials: I. Mirea (a), L. Tîrlă (b, c), N. Cruceru (d).

A clear difference between the shapes of cave ceiling and floor can be noticed. Ceiling morphology is quite uniform. Its planarity and dip indicate a structural control that we found to be directly related to foliation planes in the metacarbonate bedrock. In this idea, the cave most probably developed along the intersection of two planar features - a fracture opened along a foliation plane, and a fault. The floor is almost completely covered with breakdown interspersed with patches of clayey sediment. Several steps indicate tectonic floor breaks matching to ceiling breaks. The steps range between 0.9 and 2 meters in height. The Pocket's inclined floor is coated with calcite flowstone, slowly, but constantly fed by percolating water. Infiltration is active all inside the cave, mostly in this part, where a small creek forms and flows down over a 2-meters high step.

\subsection{Speleothems}

The cave is modestly decorated with speleothems, which is common for cavities developed in marbles.
The dense network of recrystallized calcite and increased quantity of impurities (e.g. argillaceous minerals) hamper marble dissolution and hence calcite precipitation (Ford \& Williams, 2007; Onac, 2000). However, several speleothem types can be found here: flowstone draperies with serrated edges, micro-rimstones developed on the surface of flowstones, stalactites, straws, stalagmites, and helictites (Photo 3).

Draperies. Planarity and dip of the ceiling has favored calcite precipitation as asymmetric flowstones, commonly known as draperies (Field, 2002). In the M3-R2 cave, draperies have developed on the ceiling along fractures and joints and present saw-teeth serrated edges or fringes (Boga, 1997). This shape resulted by the organization of calcite crystalline network under the control of irregularities trapped on the drapery edge (Palmer, 2007).

Moonmilk. Abundance of active moonmilk is typical for this cave compared to other types of calcite precipitates. It is a microcrystalline aggregate found in M3-R2 as white patches of calcite 
precipitation especially on flowstones and sided stalagmites. Frequently, moonmilk is the only speleothem present in cold, high-altitude or highlatitude caves, where massive calcite speleothems such as stalagmites do not form (Borsato et al., 2000; Hill \& Forti, 1997; Onac \& Ghergari, 1993). Moonmilk has been attributed to a combination of both physico-chemical and biogenic processes (Onac \& Ghergari, 1993), though scientific debates are far more complex, depending on each cave environment and setting.

Cacchio et al. (2014) stated that 'microbial activity at a constant and optimum temperature appears to be a key factor promoting calcite precipitation and moonmilk formation'.

Stalactites and stalagmites. Only several stalagmites in the cave chambers are significant (about 5 or 6), most of them very old (MIS 5 or possibly older). One sampled stalagmite (M3-R2/01) was subject to detailed isotope analysis and U-Th dating by Drăgușin (2013), who found that it formed during the warmest period of the Last Interglacial (MIS 5e). These types of speleothems are more abundant in the 'Pocket' and its small adjacent passages, where active water infiltration contributes to calcite precipitation and speleothem growth.
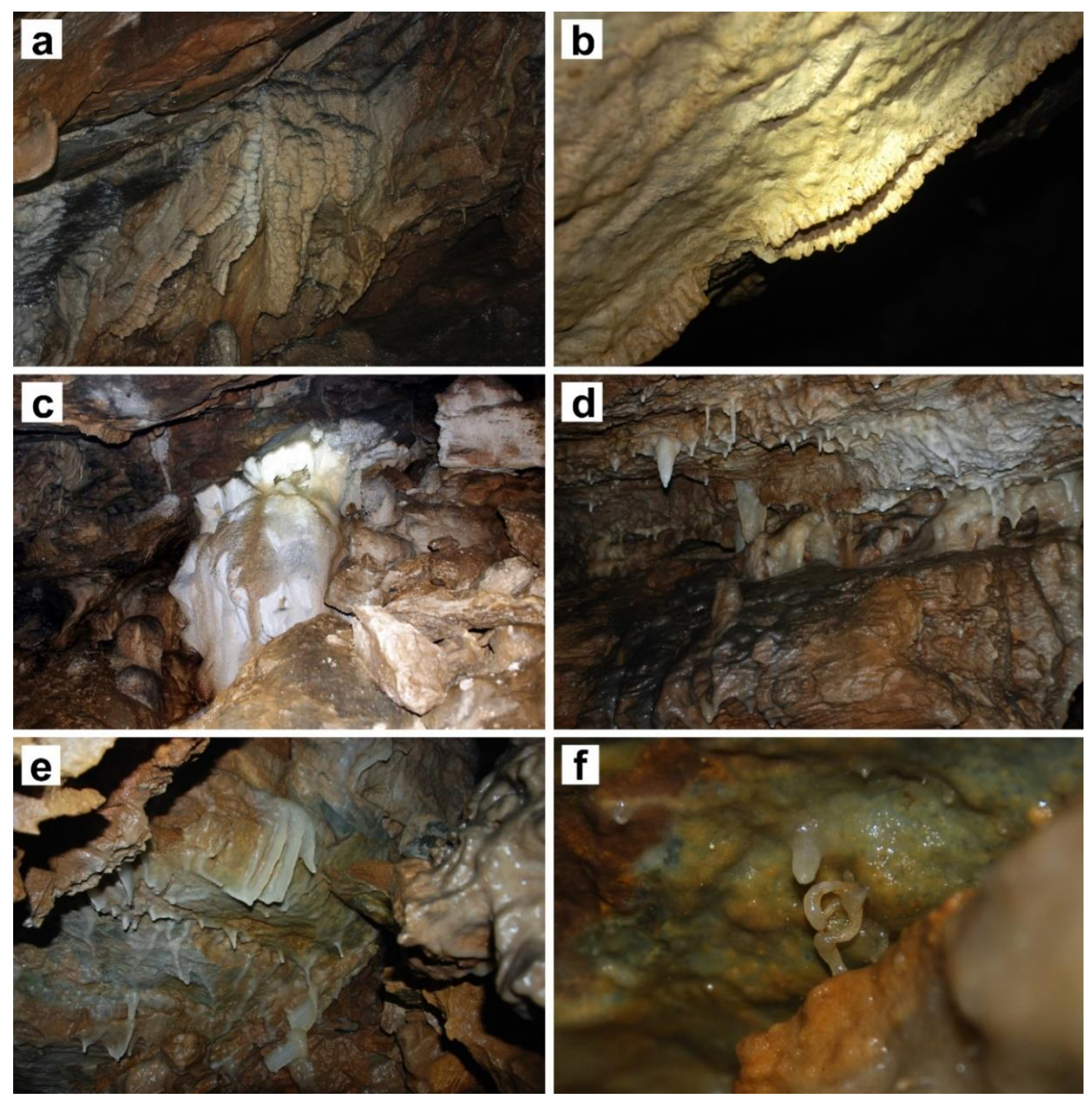

Figure 6 Speleothems from M3-R2 cave: a, b. Draperies with corrosion-shaped serrated edges; c. Massive flowstones covered by brilliant white moonmilk; $d$. Stalagmites and stalactites; e. Young draperies; f. Tiny helictite grown in a small niche from 'The Pocket' (water drops for scale). 


\subsection{Breakdown morphology}

Breakdown morphology is typical for M3-R2 cave. Fallen blocks range from centimeter- sized small pieces to meter-sized slabs. Accumulations of breakdowns are frequently cemented with recrystallized calcite, particularly in the large chamber. Such type of breakdowns was taken as evidence for very deep freezing temperatures during the Pleistocene glacial maxima (White and White, 2000). Breakdown and slow calcite precipitation under the control of infiltration water are currently the most dominant processes that shape the cave main passage. Breakdown processes are most active during the enlargement and decay phases of cave development (White, 2012), the last being the most plausible in case of M3-R2 cave.

\subsection{Cave morphometry}

The cave pattern is simple, developed under the control of a rectangular fracture network inside the metacarbonate bedrock. Two quasi-perpendicular major fractures are visible, NW-SE- $\left(155^{\circ}\right)$ and NESW- $\left(45^{\circ}\right)$ oriented, respectively.

The main NE-SW-oriented fracture, where cave entrance is located, intersects the mountain topography, which leads to the assumption that most probably the cave's main passage was longer than at present, but it has progressively been eroded as the bedrock was removed by erosion. In this sense, speleothem morphology should also be considered. The most developed stalagmites and flowstones have grown in a stable underground environment, at depths and distances from the cave entrance where external climate oscillations could not have influenced them.
The microtectonic pattern of bedrock joint sets has revealed an orthogonal joint network reflected on passage orientations (Fig. 7). This is typical to extensional forces acting upon the bedrock, different from conjugate (shear) joint sets, which tend to merge with the first set at angles from $30^{\circ}$ to $60^{\circ}$, often around $45^{\circ}$ (e.g. Davis et al., 2012).

Morphometric analysis was resumed by three main parameters, conventionally accepted as being essential for cave morphometry: development, extension, and depth (Povară et al., 1990). The cave pattern is schematically illustrated in Figure 7. It consists in 10 segments or passages with various lengths and orientations (Table 1). The total cumulative projected length of cave passages is $47 \mathrm{~m}$ and represents the cave development. Additionally, calculations accounted for the tridimensional projection of all passages (Table 1, Fig. 7). Slope ranges from $5-7^{\circ}$ to $45^{\circ}-50^{\circ}$, averaging $\sim 40^{\circ}$. It is comparable to measured foliations in the marbles dipping $27^{\circ}-35^{\circ}$.

The length of the two remnant passages with entrances located in the collapse sinkhole was not considered, because they are not physically linked to the cave at the moment. Even if the $B$ passage is part of the karst system, it is completely blocked with breakdown and access into the cave is not possible through it. Extension is given by distance between the extreme points of the cave, $21 \mathrm{~m}$. Cave depth is $-18.15 \mathrm{~m}$. Previous morphometric data reported by Giurgiu (2006) were different compared to our results, especially the length of cave passages (86 $\mathrm{m}$ ?). These may have resulted due to the lengths of all remnant passages (now disconnected from the cave), which were considered in the measurements, as well as to some morphological changes that occurred since the initial survey.

Table 1 The main parameters of cave passages

\begin{tabular}{ccccccc}
\hline $\begin{array}{c}\text { Passage } \\
\text { ID }\end{array}$ & $\begin{array}{c}\text { Projected } \\
\text { distance }(\mathbf{m})\end{array}$ & $\begin{array}{c}\text { Real distance } \\
(\mathbf{m})\end{array}$ & Width $(\mathbf{m})$ & Height $(\mathbf{m})$ & Orientation $\left({ }^{\circ}\right)$ & Slope $\left({ }^{\circ}\right)$ \\
\hline P1 & 1.7 & 1.9 & 0.8 & 0.7 & 110 & 25 \\
P2 & 2.4 & 2.8 & 2.1 & 0.8 & 65 & 30 \\
P3 & 7.8 & 9.5 & 4.2 & 2.2 & 148 & 35 \\
P4 & 16.0 & 22.6 & 8.3 & 3.2 & 40 & 45 \\
P5 & 2.3 & 2.3 & 1.7 & 0.7 & 125 & 5 \\
P6 & 5.8 & 5.9 & 1.9 & 0.7 & 102 & 10 \\
P7 & 3.4 & 3.4 & 1.2 & 1.5 & 165 & 5 \\
P8 & 1.9 & 2.3 & 0.6 & 0.3 & 157 & 35 \\
P9 & 2.9 & 3.2 & 0.5 & 0.3 & 143 & 25 \\
P10 & 2.7 & 3.0 & 0.8 & 0.5 & 13 & 25 \\
\hline
\end{tabular}




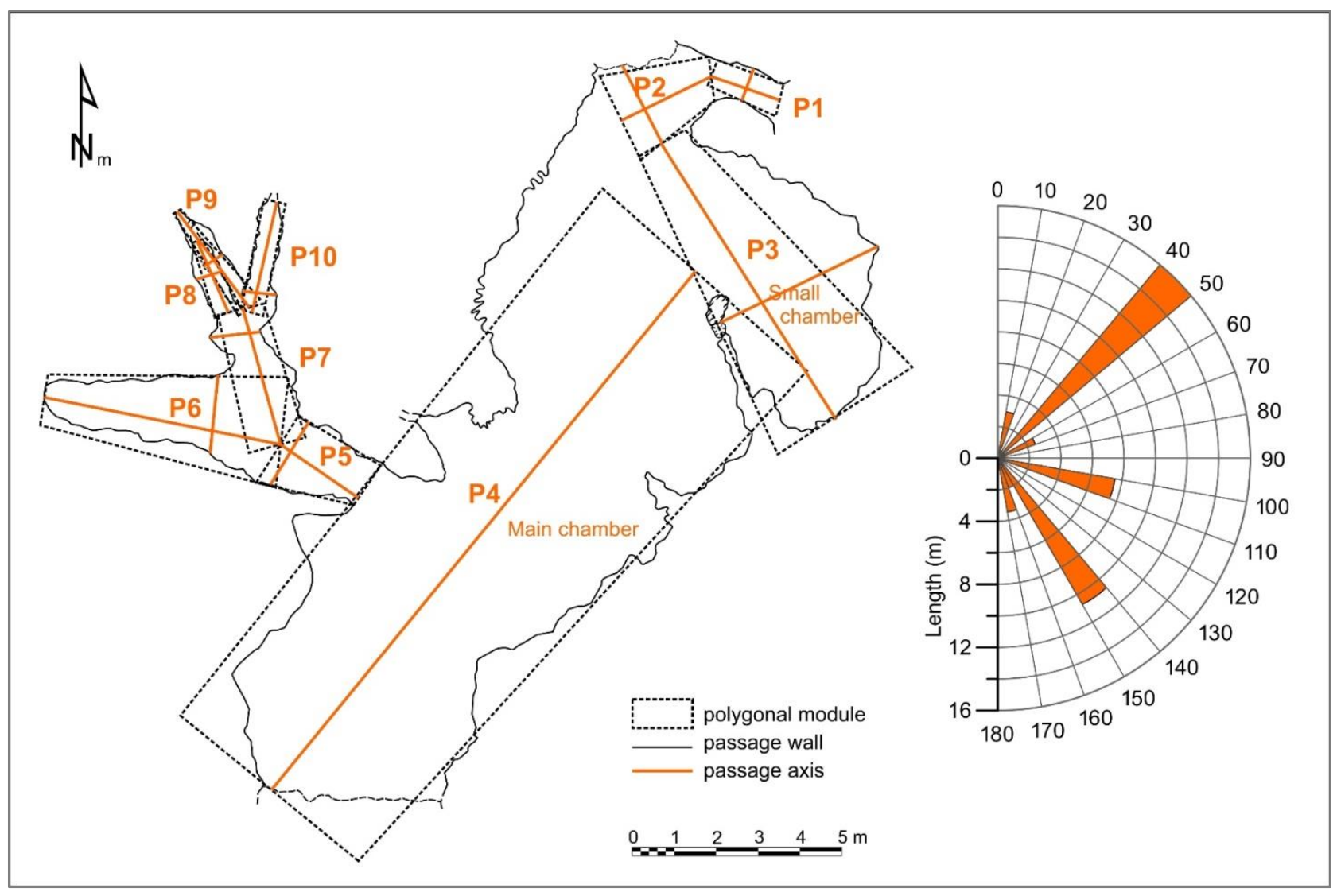

Figure 7 M3-R2 cave passages $\left(P_{n}\right)$ and rose diagram showing orientations of cumulative lengths

\section{Conclusions}

A new map of M3-R2 was created using modern survey and mapping techniques. It shows the two main morphological components of the cave: speleothems and breakdown. Stalagmites, draperies and moonmilk are the most dominant forms of calcite precipitation. Biogenic activity in a cold, alpine environment is most probably responsible for moonmilk abundance. Breakdown morphology is the other dominant component. Agglomerations of breakdown were stabilized by cementation with recrystallized calcite. The floor is partly covered by clay formed by infiltration of impurities resulted from alteration processes in the marble bedrock.

Morphometric data indicate that it is a small cave, with no spectacular sizes. It has $47 \mathrm{~m}$ in length, $21 \mathrm{~m}$ in extension and $-18.15 \mathrm{~m}$ in depth. It is a remnant of a probably longer karst system, reduced to several passages due to mountain slope retrogression caused by erosion. Formation of welldeveloped speleothems could not have been possible unless in a stable underground environment, hardly influenced by external factors.

This study was prepared to serve for further research on karst in the central area of Făgăraș Mountains, considering the high potential of alpine karst to provide valuable information on the Quaternary evolution of South Carpathians.

\section{Acknowledgements}

This study was financially supported by the IFA-CEA Grant No. C4-08/2014-2016, 'Climate change teleconnections between Western and Eastern Europe based on speleothem records of the Last Interglacial in France and Romania (FREem)'. We gratefully acknowledge I. Șandric (ESRI Romania) and A. Nedelea (University of Bucharest) for providing a part of the necessary materials used for field work and data processing. We thank M. Vlaicu from the Emil Racoviță Institute of Speleology (Romanian Academy) for suggestions regarding cave map improvements. 


\section{References}

Balintoni I. 1986. Considerations on a preliminary structural model of the South Carpathian crystalline east of the Olt river. D.S. Inst. Geol. Geofiz. 70-71(5): 23-44.

Boga S. 1997. Caving. Stackpole Books, Mechanicsburg, $195 \mathrm{p}$.

Bögli A. 1980. Karst Hydrology and Physical Speleology. Springer-Verlag, Berlin, $284 \mathrm{p}$.

Borsato A, Frisia S, Jones B, Van Der Borg K. 2000. Calcite moonmilk: Crystal morphology and environment of formation in caves in the Italian Alps. Journal of Sedimentary Research 70: 1171-1182.

Cacchio P, Ferrini G, Ercole C, Del Gallo M, Lepidi A. 2014. Biogenicity and characterization of moonmilk in the Grotta Nera (Majella National Park, Abruzzi, central Italy). Journal of Cave and Karst Studies 76(2): 88-103.

Davis GH, Reynolds SJ, Kluth C. 2012. Structural Geology of Rocks and Regions ( $3^{\text {rd }}$ ed.). John Wiley \& Sons, New York, 839 p.

Drăgușin V. 2013. Late Pleistocene climate variability recorded in stalagmites from Romania. PhD Thesis, Babes-Bolyai University, Cluj-Napoca, 112 p.

Field MS. 2002. A Lexicon of Cave and Karst Terminology with Special to Environmental Karst Hydrology (EPA/600/R-02/003). Environmental Protection Agency, Washington DC, $214 \mathrm{p}$.

Ford D, Williams PD. 2007. Karst Hydrogeology and Geomorphology. Wiley, Chichester, 562 p.

Giurgiu I. 1990. Peșterile descoperite la peste 2000 m altitudine, completare esențială a imaginii carstului din România. Buletinul Clubului de Speologie Emil Racoviță 13: 62-75.

Giurgiu I. 2006. Peșteri din Mușeteica. Invitație în Carpați 67: 28-57.

Giușcă D, Anastasiu N, Popescu GC, Șeclăman M. 1977. Observații asupra șisturilor cristaline din zona centrală a Masivului Făgăraș (Cumpăna - V. Cârțișoara). Analele Universităţii Bucureşti, Seria Geologie XXVI: 3-17.

Häuselmann P. 2008. Basic Cave Mapping Symbols. Survey and Mapping Working Group. Retrieved
August 25, 2016 from http://www.uisic.uis-speleo. org/wgsurmap.html.

Hedberg O. 1964. Features of Afroalpine plant ecology. Almqvist and Wiksells Boktryckeri, Uppsala, $150 \mathrm{p}$.

Hill CA, Forti P. 1997. Cave Minerals of the World $2^{\text {nd }}$ edition. National Speleological Society, Huntsville, 463 p.

Lemne M, Savu H, Ștefan A, Borcoș M, Russo-Săndulescu D, Udubașa G, Vâjdea E. 1983, Report - GGI Archive (unpublished material). Institute of Geology and Geophysics, Bucharest.

Nedelea A. 2006a. Observaţii petrografice pe versantul sudic al Munţilor Făgăraş, între vârfurile Negoiu şi Moldoveanu. Comunicări de Geografie X: 55-60.

Nedelea A. 2006b. Valea Argeșului în sectorul montan: Studiu de geomorfologie. Editura Universitară, București, 229 p.

Onac BP. 2000. Geologia regiunilor carstice. Editura Didactică și Pedagogică, București, 399 p.

Onac BP, Ghergari L. 1993. Moonmilk Mineralogy in some Romanian and Norwegian Caves. Cave Science 20 (3): 107-111.

Palmer AN. 2007. Cave Geology. Cave Books, Dayton (USA), $454 \mathrm{p}$.

Povară I, Goran C, Gutt WF. 1990. Speologie: Ghid practic. Edit. Sport-Turism, București, $237 \mathrm{p}$.

Schuster AC. 1977. Geological map of Romania, scale 1:50,000, Negoiu sheet 109a (L-35-86-A). Geological Institute of Romania, Bucharest.

Sencu V. 1973. Legenda hărții carstului. St. Cerc. Geol. Geofiz. Geogr., Seria Geografie XX(1): 73-75.

Tchoukanski I. 2010. EasyCalculate 10. ESRI, Redlands. Retrieved June 17, 2016 from http://www.ianko.com/free/EC10/EC10 main.htm.

White EL. 2012. Breakdown. In: White WB, Culver DC (eds.), Encyclopedia of Caves. Elsevier-Academic Press, Waltham, 68-74.

White EL, White WB. 2000. Breakdown Morphology. In: Klimchouk A, Ford DC, Palmer AN, Dreybrodt W. (eds.), Speleogenesis: Evolution of Karst Aquifers. National Speleological Society, Huntsville, 427-429.

White WB, Culver DC. 2012. Cave, Definition of. In: White WB, Culver DC (eds.), Encyclopedia of Caves. ElsevierAcademic Press, Waltham, 103-107. 